\title{
PROCEEDINGS OF THE PATHOLOGICAL SOCIETY OF GREAT BRITAIN AND IRELAND
}

The 132nd meeting of the Society was held at the London Hospital, London, on the 7 th, 8th and 9 th January 1976

\section{SYNOPSES OF PAPERS*†}

These synopses should not be cited as references in published work without the permission of the authors.

1. Stimulation of aUtologous BLOOD LYMPHOCYTES

BY MALIGNANT LYMPHOMA CELLS AND HOMOGENATES

J. Gough and M. E. Ludgate

Department of Pathology, Welsh National School of Medicine, Cardiff

2. THE GENERAL IMMUNE STATUS AND TUMOUR DIRECTED

IMMUNE RESPONSES OF CANCER PATIENTS ASSESSED BY MULTIPLE TECHNIQUES PERFORMED SIMULTANEOUSLY

A. J. Cochran, Rona M. Mackie, Catherine E. Ross, Lindsay J. Ogg and A. M. Jackson University Departments of Pathology and Dermatology, The Western Infirmary, Glasgow G11 6NT, Scotland

3. MACROPHAGE electrophoretic MOBILITy (MEM) TEST: DIFFICULTIES AND APPLICATIONS

E. J. Field

Royal Victoria Infirmary, Newcastle-upon-Tyne

4. ON THE VALUE OF THE BERYLLIUM MACROPHAGE MIGRATION INHIBITION TEST IN THE DIAGNOSIS OF BERYLLIUM DISEASE, WITH A REPORT ON THE FIRST CASES OF CHRONIC DISEASE DETECTED IN INDUSTRIAL WORKS IN JAPAN

W. Jones Williams, C. D. Price and T. Izumi

Department of Pathology, Welsh National School of Medicine, Cardiff, and University of Kyoto, Japan

5. NON-SPECIFIC IMMUNITY IN MICE INFECTED WITH A VARIANT OF MURINE LEUKAEMIA (FRIEND)

Gillian A. Hurst and K. E. K. Rowson

Department of Pathology, Institute of Laryngology and Otology, London WCIX 8EE

* Synopses of papers on pathology are published in the Journal of Pathology.

† The programme included a tribute to the late Professor C. L. Oakley by Professor K. Zinnemann.

J. MED. MICROBIOL.—VOL. 9 (1976) Pi 
6. THE ROLE OF MACROPHAGES IN THE ADJUVANT EFFECT OF Corynebacterium parvum

V. S. Sljivic and Susan R. Watson

Department of Immunology, St Mary's Hospital Medical School, London W2 IPG

7. THE EFFECT OF Mycobacterium lepraemurium INFECTION ON IMMUNE RESPONSES IN THE MOUSE

I. N. Brown, V. S. Sljivic and S. R. Watson

Departments of Bacteriology and Immunology, Wright-Fleming Institute, St Mary's Hospital Medical School, London W2 IPG

\section{DEGRANULATION OF CHICKEN HETEROPHIL LEUCOCYTES} DURING PHAGOCYTOSIS

J. E. Trowell and D. B. Brewer

Department of Pathology, Medical School, University of Birmingham

\section{INTERNATIONAL KVEIM HISTOLOGY TRIAL}

W. Jones Williams, R. M. E. Seal, Kathleen J. Davies and J. S. Chapman Department of Pathology and Medical Statistics, Welsh National School of Medicine, Cardiff and Department of Medicine, University of Texas

\section{ASPIRIN DAMAGE IN THE RAT KIDNEY \\ E. A. Molland \\ Institute of Pathology, The London Hospital, EI}

11. Proliferation of the epithelium of the Renal pelvis and BLADDER AFTER TEMPORARY UNILATERAL RENAL ISCHAEMIA IN RATS

Susan Dunn, E. Mary Gibbons and B. M. Herbertson Department of Pathology, University of Cambridge, Tennis Court Road, Cambridge CB2 IQP

12. PRE-NEOPLASTIC CHANGES IN "NORMAL" BLADDER UROTHELIUM ADJACENT TO TUMOUR IN MAN AND RAT

J. Newman, P. M. Rowles and R. M. Hicks Bland-Sutton Institute of Pathology and School of Pathology, Middlesex Hospital Medical School, London WIP 7LD

\section{BOVINE SERUM ALBUMIN NEPHROPATHY}

D. J. Davies, D. B. Brewer and J. Hardwicke Departments of Pathology and Experimental Pathology, University of Birmingham, Birmingham B15 9TJ 
14. QUANTITATIVE ASSESSMENT OF IMMUNOGLOBULIN LEVELS IN TISSUE SECTIONS

P. Wilkins, D. Williams and E. D. Williams

The Welsh National School of Medicine, Heath Park, Cardiff

15. Diseases and histological normality of the Renal glomerulus

W. Lawler and G. Williams

Department of Pathology, University of Manchester

16. IMMUNO-ELECTRON MICROSCOPY IN MEMBRANOUS GLOMERULONEPHRITIS

D. R. Davies

Department of Morbid Anatomy, St Thomas' Hospital, London SEI

17. HiSTOLOGY AND IMMUNOPATHOLOGY OF THE LUNGS OF NEW ZEALAND BLACK/WHITE F1 HYBRID MICE

A. Leathem, D. Geddes and B. Corrin

Bland-Sutton Institute of Pathology and School of Pathology, Middlesex Hospital Medical School, London WIP 7LD

18. Chronic bronchitis and asthma. Light, immunofluorescent, AND ELECTRONMICROSCOPICAL STUDIES OF FIBREOPTIC BIOPSIES

R. C. Butler, B. Hutchcroft, D. F. Woodrow, J. Vintner, J. C. Sloper and A. Guz Charing Cross Hospital Medical School, London W6 8RF

19. Pulmonary ultrastructure after oral and intravenous DOSAGE OF PARAQUAT TO RATS

I. F. H. Purchase, B. I. Sykes and L. Smith

Imperial Chemical Industries Limited, Central Toxicology Laboratory, Alderley Park, $n r$ Macclesfield, Cheshire

20. The PUlMoNARY ARgYROPHIL CELlS IN High altitude Rabits

W. Taylor

Department of Pathology, University of Liverpool, Liverpool L69 3BX

21. ANOMAlous iliac Compliance in ChILdRen With a SINGLe UMBILICAL ARTERY: ITS RELEVANCE TO DEGENERATIVE VASCULAR DISEASE

C. L. Berry and R. G. Gosling

Departments of Histopathology and Physics, Guy's Hospital Medical School, London SEI 9RT 
22. Concealed CARDiac RUPture

J.-P. van Mantgem and A. E. Becker

Department of Pathology, University of Amsterdam, Wilhelmina Gasthuis, Amsterdam, The Netherlands

\section{Glue ear}

Ingle Wright

Department of Pathology, Stopford Building, Manchester M13 9PT

24. HUMAN ASTROCYTE CARRIER CULTURES OF MEASLES VIRUS (WILD TYPE AND EDMONSTON)-SOME ULTRASTRUCTURAL FEATURES

E. H. Macintyre and J. A. Armstrong

National Institute for Medical Research, Mill Hill and Clinical Research Centre, Harrow

25. EXAMINATION OF TISSUE OCCLUDING VENTRICULO-ATRIAL SHUNTS FROM HYDROCEPHALICS: A PRELIMINARY STUDY

Patricia Collins and A. Hockley

Department of Anatomy, and Addenbrookes Hospital, Cambridge

26. HEPATIC NODULAR HYPERPLASIA AND CANCER PRODUCED BY PONCEAU MX IN RATS

P. Grasso, M. G. Wright and T. J. B. Gray

BIBRA, Carshalton, Surrey SM5 4DS

27. THE LIVER IN MALABSORPTION

D. J. Pollock

Institute of Pathology, London Hospital Medical College, Whitechapel, London EI IBB

SYMPOSIUM : IMMUNOPATHOLOGY OF LYMPHOID TUMOURS

Chairman: Professor R. B. Goudie

28. THE LIFE CYCLE OF LYMPHOCYTES

R. B. Goudie

University Department of Pathology, Royal Infirmary, Glasgow

29. THE HISTOLOGICAL CLASSIFICATION OF NON-HODGKIN'S LYMPHOMAS

D. H. Wright

University of Southampton Medical School, Southampton General Hospital 
OF GREAT BRITAIN AND IRELAND

30. DISORDERED IMMUNITY IN LYMPHOMAS

G. L. Asherson

Clinical Research Centre, Northwick Park, Middlesex

\section{Autoimmunity and Lymphoma}

R. N. M. MacSween

University Department of Pathology, Western Infirmary, Glasgow

32. NUCLEAR ACCEPTOR DEFECT FOR GLUCOCORTICOID RECEPTORS IN BURKITT'S LYMPHOMA CELL LINES

C. C. Bird, J. M. Dixon and A. R. Currie

University Department of Pathology, Teviot Place, Edinburgh

\section{HODGKIN'S DISEASE}

G. Farrer-Brown ${ }^{1}$, M. H. Bennett ${ }^{2}$, Kristin Henry ${ }^{3}$ and A. M. Jelliffe 1

Bland-Sutton Institute of Pathology ${ }^{1}$, Middlesex Hospital, London WI, Department of Histopathy2, Mount Vernon Hospital, Northwood, Middlesex and Department of Histopathy3,

Westminster Hospital Medical School, London SWI

\section{SCLEROSIS IN NON-HODGKIN'S LYMPHOMAS}

M. H. Bennett

Department of Pathology, Mount Vernon Hospital, Northwood, Middlesex

35. B-CELL DIFFERENTIATION IN LYMPHOMA

J. Habeshaw and A. E. Stuart

Department of Pathology, University of Edinburgh, Teviot Place, Edinburgh EH8 $9 A G$

36. NON-HODGKIN'S LYMPHOMA: HISTOLOGY COMPARED WITH RECEPTOR PATTERNS

R. A. Macaulay and A. E. Stuart

Department of Pathology, University of Edinburgh, Teviot Place, Edinburgh EH8 9 AG

\section{Primary gastrointestinal Lymphoma}

Kristin Henry, Catherine Howarth and G. Farrer-Brown

Bland-Sutton Institute of Pathology, Middlesex Hospital and

Westminster Medical School, London 


\title{
P vi PROCEEDINGS OF THE PATHOLOGICAL SOCIETY
}

\section{THE PRODUCTION OF URINARY PHENOLS BY HUMAN GUT BACTERIA}

\author{
Elizabeth S. Bone, A. Tamm and M. J. Hill \\ Bacterial Metabolism Research Laboratory, Central Public Health Laboratory, \\ Colindale, London NW9 5DX
}

Normal adults excrete approximately $50 \mathrm{mg}$ of volatile phenols per day in their urine, principally $p$-cresol (which accounts for about $90 \%$ of the total) and phenol. It has been established by a number of groups that these volatile phenols are entirely produced by gut bacterial metabolism of tyrosine. Our interest in these phenols stems in part from their co-carcinogenic properties and hence their possible role in large bowel cancer.

Sixty strains of human gut bacteria have been tested for their ability to metabolise tyrosine to volatile phenols in vitro; in general aerotolerant organisms produced phenol whilst anaerobes produced $p$-cresol.

We have also assayed the urinary volatile phenols in various groups of patients. Patients with familial polyposis produced only small amounts of volatile phenols; the lack of bacterial activity towards tyrosine was in agreement with the results reported last year towards other amino acids and towards steroids. In contrast, patients with small intestinal colonisation produced much more urinary volatile phenol per day than normal, and the ratio phenol : $p$-cresol was $>2$ compared with about $0 \cdot 1$ in normal persons. Since the small intestinal organisms were mainly aerobic these results are compatible with our in-vitro results with pure cultures of bacteria.

\section{TRYPTOPHAN METABOLISM BY HUMAN GUT BACTERIA}

Elizabeth S. Bone

\author{
Bacterial Metabolism Research Laboratory, Central Public Health Laboratory, \\ Colindale, London NW9 5DX
}

A wide range of tryptophan metabolites are excreted in normal human urine; these are normally assumed to be the products of hepatic metabolism although all have been shown to be produced by bacteria of non-intestinal origin. A number of these metabolites have been shown to be co-carcinogenic; if they are produced in the gut, they might be involved in the aetiology of large bowel cancer. It is necessary, therefore, to determine

(a) which of the metabolites can be produced by bacteria of intestinal origin in vitro,

(b) which are in fact produced in vivo, and

(c) whether the amounts are significant.

This report contains preliminary data on the first two questions.

In-vitro studies show that gut bacteria can produce a wide range of metabolites from tryptophan, many of which have still to be identified. Indole, indoleacetic acid and indolepropionic acid are produced by organisms of a range of genera, whilst clostridia have been shown to produce a kynurenine derivative and kynurenic acid.

Faecal samples from people living in various countries have been assayed for tryptophan and for bacterial tryptophanase. The populations at greater risk of large bowel cancer have higher faecal concentrations of this substrate and of this enzyme. Whether the tryptophan is derived from the diet or from sloughed mucosal cells is not known.

\section{DECARBOXYLASE ACTIVITY OF ANAEROBIC BACTERIA}

Katherine Johnson and B. S. Drasar

Bacterial Metabolism Research Laboratory, Central Public Health Laboratory, Colindale Avenue, London NW9 5DX

The ability of bacteria to decarboxylate amino acids has long been an important aspect of procedures for their identification. Methods used for the testing of aerobic bacteria are 
unsuitable for the testing of anaerobic organisms. Problems arise as a result of the reduction of indicators under anaerobic conditions and the destruction of indicators by bacterial action. Media used for the growth of aerobic and facultatively aerobic organisms often require enrichment before they will support the growth of anaerobic organisms.

The ability of anaerobic bacteria to decarboxylate the amino acids lysine, ornithine and arginine was investigated. Various test systems were compared. The occurrence of decarboxylase activity was confirmed by the analysis of the incubation mixtures by thin layer chromatography.

Strains of bacteroides including Bacteroides fragilis did not attack the amino acids tested. In contrast strains of Fusobacterium (Sphaerophorus) varius decarboxylated lysine. Ornithine was decarboxylated by strains of Clostridium septicum.

\title{
41. The initial LESION IN INTESTINAL AMOEBIASIS
}

\author{
R. G. Bird and T. F. McCaul \\ Electron Microscopy Unit, London School of Hygiene and Tropical Medicine, \\ Keppel Street, London WCIE 7 HT
}

An essential element in the initial lesion of intestinal amoebiasis has been shown, both in vivo and in vitro, to be contact between the pathogenic amoebae and cell surfaces. Mechanisms operative on or after cell contact and the micromilieu necessary for pathogenicity have been studied by many workers. Our recent studies on enzymes in a known pathogenic strain of Entamoeba histolytica, on RK13 cell line, and the two together, indicate that no one particular enzyme can be incriminated with cytolysis.

Viral genome carried by amoebae may play a secondary role in cell destruction; however, a toxin affecting membrane permeability causing loss of intracellular soluble proteins and ionic inbalance is now thought to be the primary operative factor in pathogenesis. Unblocked secondary factors, independently or together, may then lead on to cell destruction. If the balance between cell destruction and cell repair is upset the result is amoebiasis. It appears that cell contact is required for transfer of this toxin.

Biochemical assay is extremely difficult when only limited samples of amoebae are available, but it is now important that we establish the true nature of the plasmalemma in pathogenic strains of E. histolytica, especially with respect to lipoprotien and $m \mu$ copolysaccharide content.

\section{INBRED MOUSE STRAINS AND THE GENETICS OF THEIR RESISTANCE TO Salmonella typhimurium INFECTION}

Janet Plant and A. A. Glynn

\author{
Bacteriology Department, Wright-Fleming Institute, St Mary's Hospital Medical School, \\ London W2 IPG
}

After subcutaneous infection with Salmonella typhimurium C5, eight inbred mouse strains could be divided into two distinct groups. Four strains were very susceptible to infection with LD50's of less than 100 and four were resistant to doses of more than $10^{5}$ organisms.

The possibility of genetic control of resistance to $S$. typhimurium infection was studied in a sensitive mouse strain, Balb/c, and a very resistant strain, CBA. The $F_{1}$ generation was as resistant as the CBA parent, the infection developing similarly in the organs of the two strains.

By comparison of the kinetics of infection in sensitive and resistant mice we could determine susceptibility to Salmonella of individual mice from the mixed hybrid populations, the $F 1 \times B a l b / c$ back-cross and the $F_{2}$ generations. We have demonstrated Mendelian 


\section{P viii PROCEEDINGS OF THE PATHOLOGICAL SOCIETY}

dominance and an oligogenic control of resistance to S. typhimurium. Possible marker genes, including the $\mathrm{H}-2$ locus, have been looked for, so far unsuccessfully.

$S$. typhimurium-infected mice develop a delayed hypersensitivity reaction to the injection of a salmonella extract into the footpad. The reaction is more intense in the resistant than in the sensitive mouse strain. The intensity in the hybrid generations is now being studied.

\section{CAN VACCINIA VIRUS SURVIVE IN THE COCKROACH DURING FUMIGATION?}

B. Baker, C. Bartzokas, K. McCarthy and B. Shackleton

Department of Medical Microbiology, Liverpool University

Living flies observed by chance on opening an animal room which had been sealed and fumigated overnight with gaseous formaldehyde cast doubts on the standard B.P. procedure recommended by DHSS for disinfecting infected rooms.

Tests with flies and cockroaches confirmed the fact, not widely known, that some insects are remarkably tolerant to formaldehyde. A film illustrated "pockrophagy" by cockroaches and the results were presented of attempts to recover vaccinia virus from experimentally infected cockroaches exposed in fumigated rooms overnight.

\section{QUantitative STUDIES OF INTERACTIONS AMONG SKIN ORGANISMS ON SOLID SURFACES}

Rajaa M. Milyani and S. Selwyn

\section{Department of Bacteriology, Westminster Medical School, London SWIP 2AR}

In our earlier quantitative work on mixed cultures of skin micro-organisms, liquid systems were used almost exclusively. Although the established methods of batch culture and continuous culture (in the chemostat) possess many valuable features, these procedures do not reproduce closely the conditions under which micro-organisms grow on the human epidermis. Quantitative methods have therefore been developed for studying the growth kinetics of skin organisms in mixed cultures on solid surfaces. The equivalent of liquid batch cultures are prepared on suitable solid media from which precisely demarcated portions are excised at regular intervals. Differential viable counts are then made on selective media to allow the construction of mixed growth curves. The development of a system for the study of mixed continuous cultures on solid surfaces has proved to be a far more difficult problem. However, a prototype apparatus has now been built which allows the long-term investigation of microbial interactions in a chemostat. This provides both solid and liquid phase conditions. The effects of antibiotic-producing skin organisms on relevant bacteria and fungi have been studied in detail, as have synergistic activities of some cultures. The results were discussed in relation to skin ecology.

\section{Production of antibiotics By DeRMatophyte FUngi}

Nagwan Youssef, C. Wyborn, G. Holt, W. C. Noble* and Yvonne M. Clayton*

Department of Life Sciences, Polytechnic of Central London and Institute of Dermatology*, London

Ecological studies have suggested that antibiotic production by dermatophyte fungi may bring about changes in the antibiotic sensitivity patterns of bacteria in skin lesions.

The antibiotic activity of 27 clinical isolates of dermatophytes grown in shake flasks in a fermentation medium designed for maximal benzyl penicillin production have been investigated. At $26^{\circ} \mathrm{C}, 30^{\circ} \mathrm{C}$ and $33^{\circ} \mathrm{C}$, all 8 strains of Trichophyton mentagrophytes tested produced 
antibiotic, while 6 of 11 strains of T. rubrum and 4 of 8 strains of Epidermophyton floccosum also showed activity.

The same medium was shown to support the production of several different antibiotics by some of these strains. A preliminary classification of antibiotics elaborated includes benzyl penicillin (by representatives of all three species), 6-amino penicillanic acid and streptomycin (by representatives of $T$. mentagrophytes and $T$. rubrum only) as well as an antibiotic with properties similar to azalomycin (by some strains of $E$. floccosum only).

Techniques have been devised which allow recognition of antibiotic production from dermatophytes grown on human epidermis in vitro. Some isolates of both $T$. mentagrophytes and $T$. rubrum which synthesise antibiotic in a fermentation medium also do so on epidermis. So far no antibiotic activity on epidermis has been demonstrated for cultures of $E$. floccosum.

\title{
46. ROLE OF STAPHYLOCOCCAL VIRULENCE FACTORS AND COMPLEMENT IN DIFFERENT SITES OF INFECTION IN THE MOUSE
}

\author{
C. S. F. Easmon and A. A. Glynn \\ Bacteriology Department, Wright-Fleming Institute, \\ St Mary's Hospital Medical School, London W2 IPG
}

From a comparison of the effects produced by injecting different strains of Staphylococcus aureus either subcutaneously or intraperitoneally into mice it is possible to assess the pathogenic significance of various staphylococcal virulence factors in the two sites of infection. In skin lesions the inflammation-suppressing factor found in the cell walls of strain PS80 plays a major role. In contrast, in intraperitoneal infection the antiphagocytic capsule of the SD and M strains is more important. All strains used produced $\alpha$ haemolysin which is the ultimate lethal agent in intraperitoneal infection but is only one factor in the production of dermonecrosis.

Both C3 and C5 were needed in the production of fluid exudate in response to staphylococcal skin infection. C3 appears to be more important in the increased exudate formed in immune mice. In the peritoneum, the opsonic and chemotactic actions of complement are important, as shown by the results in cobra-venom-treated normal mice and in C5 deficient B10D2 old-line mice.

47. THE ROLE OF GROWTH RATES OF Micrococcus SUBGROUP 3 (Staphylococcus saprophyticus BIOTYPE 3) IN THE PATHOGENESIS OF URINARY-TRACT INFECTIONS

J. D. Anderson, H. L. Forshaw, Monica A. Adams, W. A. Gillespie* and Margaret A. Sellin*

Infection Control Laboratory, Clifton Hospital, York, YO3 6RD and Department of Bacteriology, University of Bristol*, Bristol BS8 ITD

Novobiocin-resistant biotypes of Micrococcus subgroup 3 (Staphylococcus saprophyticus) are primary pathogens of the female urinary tract and cause infections as severe as those by Escherichia coli. The growth characteristics of this virulent biotype were compared in vitro with other Micrococcaceae and $E$. coli to determine whether rapid growth explains the virulence of this organism in the urinary tract.

Nutrient broth was shown to be unsuitable for those studies. The virulent biotype grew more slowly and reached a lower final viable count in urine than either $E$. coli or a range of other Micrococcaceae isolated from healthy women. Urine from women recently infected with the virulent biotype had similar growth supporting properties to urine from healthy women. 
Experiments with forestream specimens of urine suggested that urethral secretions do not contain a factor which promotes growth of the virulent biotype in urine. The possibility that virulent strains adapt to rapid growth in urine was excluded. No evidence was obtained that the virulent biotype inhibits the growth of other Micrococcaceae in urine.

Growth rates in urine do not, therefore, appear to explain the enhanced virulence of novobiocin-resistant strains of subgroup 3 micrococci over other Micrococcaceae.

48. EXPERIMENTAL URINARY-TRACT INFECTIONS IN MICE WITH Escherichia coli STRAINS OF DIFFERING K ANTIGEN CONTENT

Andrea M. Nicholson and A. A. Glynn

Bacteriology Department, Wright-Fleming Institute, St Mary's Hospital Medical School, London W2 IPG

Previous work has shown that the quantity and activity of $\mathrm{K}$ antigen present in strains of Escherichia coli is correlated with the virulence of the strains for mice, and with the ability of the organisms to resist phagocytosis and complement killing. Strains of $E$. coli from the urine of women with urinary-tract infection are more frequently rich in $\mathrm{K}$ antigen than faecal strains. The excess of $\mathrm{K}$-rich strains is due to patients who have renal and not solely bladder infections. Thus although strains of $E$. coli may reach the bladder in proportion to their frequency in the faeces, strains rich in $\mathrm{K}$ antigen are more likely to succeed in invading the kidney.

In order to study experimentally urinary-tract disease due to $E$. coli a model of infection in mice was developed. Two small silk stitches were inserted into the bladder walls of anaesethetised mice. The injection of bacteria into the bladder lumen then initiated an acute urinary-tract infection.

Porton male mice were infected with various doses of $E$. coli strains of differing $\mathrm{K}$ antigen contents. The infectivity of the bacteria for mouse kidneys was found to be determined by both the amount and the activity of the $\mathrm{K}$ antigen present in the organism.

\footnotetext{
49. A SCHEME FOR THE IDENTIFICATION OF CLINICALLY IMPORTANT

GRAM-NEGATIVE ANAEROBIC BACILLI BY SIMPLE BACTERIOLOGICAL TESTS
}

\author{
B. I. Duerden, W. P. Holbrook, J. G. Collee and B. Watt \\ Department of Bacteriology, Edinburgh University Medical School, and \\ Central Microbiological Laboratories, Edinburgh
}

We have subjected 220 reference strains and laboratory isolates of gram-negative nonsporing non-motile anaerobic bacilli to a series of simple laboratory tests that included conventional biochemical tests, tests of resistance to antibiotics, and tolerance to dyes and bile salts. These tests were poised for use with gram-negative anaerobic bacilli and allowed clear separation of strains into three main groups: Bacteroides fragilis, B. melaninogenicus and Fusobacterium species. Certain tests were found useful for identifying the recognised subspecies of $B$. fragilis and $B$. melaninogenicus. We have selected a short set of simple tests that have particular discriminative value and we present a scheme for the identification of unknown isolates of gram-negative anaerobic bacilli. The tests are: pigment production; antibiotic disk resistance tests with neomycin $(1000 \mu \mathrm{g})$, kanamycin $(1000 \mu \mathrm{g})$, penicillin $(1.5$ units) and rifampicin $(15 \mu \mathrm{g})$; tolerance tests with sodium taurocholate $(0.5 \%)$, sodium deoxycholate $(0 \cdot 1 \%)$, Victoria blue $4 \mathrm{R}(1$ in 80000$)$, and ethyl violet $(1$ in 80000$)$; and conventional biochemical tests for the production of indole, hydrolysis of aesculin, digestion of gelatin, and fermentation of glucose, rhamnose, trehalose, and mannitol. The determination of these species and certain sub-species is of clinical significance and our procedures could be routinely applied in a conventionally equipped service laboratory. 


\title{
SYMPOSIUM: THE PATHOLOGY AND TREATMENT OF HERPESVIRUS INFECTIONS \\ Chairman: Professor A. P. Waterson
}

\section{HeRpesvirus infeCtions in ImMUNosupPRESSEd PATIENTS}

\author{
K. A. Porter \\ Department of Pathology, St Mary's Hospital Medical School, London W2
}

Patients who are immunologically less competent than normal, in particular those that have a defect of cell mediated immunity, are more likely to develop viral infections. The immunological incompetence may be due to some congenital defect, to pregnancy, to a disease such as Hodgkin's or to the therapeutic administration of immunosuppressive agents. Among the virus infections encountered in these patients those due to members of the herpes group are particularly common. The infections tend to be persistent, often upleasant and may become generalised affecting visceral organs and occasionally causing death. Most are due to activation of a latent infection. After immunosuppression for organ transplantation some of these virus infections are closely associated with episodes of acute rejection and cytomegalovirus may cause swelling of the cells lining the cystic duct of a liver graft or the ureter of a kidney graft producing obstruction. Herpes viruses also seem to be implicated in the production of immune complex glomerulonephritis. Their relationship to the increased incidence of malignancies in immunosuppressed patients is less clear.

\section{HeRPESVIRUS INFECTIONS}

\section{T. H. Flewett \\ Regional Virus Laboratory, East Birmingham Hospital}

Most infections by herpes-group viruses are well known. But sometimes herpes simplex and cytomegaloviruses cause unusual clinical presentations. Herpes febrilis virus is known occasionally to cause acute focal necrosis in liver and adrenals of neonates, but not in older children. But in acute protein deficiency (Kwashiorkor), this pattern appears up to the age of 5 or 6 . A very few adult cases are known, usually associated with primary stomatitis and some kind of stress on the liver. In patients with immunological deficiency and in the immuno-suppressed, herpes simplex and cytomegalovirus sometimes cause generalised infection, zoster-like syndromes and intestinal symptoms.

\section{HERPES ENCEPHALITIS-DIAGNOSIS AND TREATMENT}

\section{Longson \\ Royal Infirmary, Glasgow}

Three, or possibly all four, human herpesviruses (Herpesvirus simplex, Herpesvirus varicellae, cytomegalovirus and Epstein-Barr virus) can be incriminated in the aetiology of acute polioclastic viral encephalitis. In each instance, there is direct involvement of the virus in the pathological process which is occurring in nervous tissue and the disease, so caused, has to be distinguished from diffuse perivascular leucoencephalitis of post-infective or " allergic " origin.

The term " herpes encephalitis " is usually reserved for the most severe of the Herpesvirus encephalitides, and is caused by Herpesvirus simplex. This is an acute necrotising encephalitis which, in its classical (Van Bogaert) form, affects predominantly one or other lobe of the brain, but it can present as a diffuse process in one, or both cerebral hemispheres.

The diagnosis of Herpesvirus simplex encephalitis is suspected on the basis of clinical, 
clectroencephalographic and radiological findings, but must remain in doubt until at least one of the following conditions is fulfilled:

(1) the identification of Herpesvirus simplex in brain tissue (biopsy or necropsy) by immunofluorescence or culture, and $/$ or

(2) the appearance of specific antibody to Herpesvirus simplex alone in cerebrospinal fluid (late phenomenon), and/or

(3) uncontroversial histopathological evidence of herpetic infection of the brain (Lipschutz inclusions, or ultrastructural identification of virus particles), together with at least a four-fold arise in antibody to Herpesvirus simplex in the serum.

The treatment of Herpesvirus simplex encephalitis appears to reside first and foremost in adequate medical, or possibly surgical, decompression of the brain and very good general and respiratory supportive care. The value of specific antiviral drugs such as idoxuridine, adenine arabinoside and cytosine arabinoside is controversial, but may be resolved by the double-blind trials now in progress.

\title{
53. CHEMOTHERAPY OF HERPES INFECTIONS: THE PRESENT POSITION
}

\section{J. Bauer}

\section{Wellcome Research Laboratories, Beckenham, Kent}

Four compounds are in clinical use in the treatment of infections caused by the herpes group of viruses, namely vidarabine, trifluorothymidine, idoxuridine and cytarabine. They vary widely in potency, and if the activity of vidarabine is taken as 1 , the values for the other compounds are 10,16 and 75 respectively. Type- 2 strains of herpes are reported to be less sensitive than type-1, but examination of a series of strains of both types has shown that their sensitivities mostly overlap.

The compounds are all DNA antagonists, and have a number of toxic side-effects. Their systemic use is restricted by the fact that they have short half-lives and are rapidly metabolised to compounds with lesser or no antiviral activity. When given topically they are effective in the treatment of herpetic keratitis, cutaneous herpes and zoster, and they are undergoing evaluation in the treatment of genital herpes. Their use in the treatment of herpetic encephalitis has not yet proved effective, and is beset with problems of half-life and penetration of the blood-brain barrier. There are conflicting reports on the value of intravenous cytarabine in the treatment of varicella and generalised zoster. Success must depend on the maintenance of adequate antiviral concentrations without undue depression of immune response. Idoxuridine has been used in the treatment of congenital cytomegalovirus infection, but little has been achieved apart from temporary inhibition of the excretion of virus.

\section{Detection OF TYPE SPECIFIC ANTIBODY TO HERPESVIRUS TYPES 1} AND 2 IN HUMAN SERA

\author{
G. R. B. Skinner, S. Trueman and C. Hartley \\ Department of Virology, The Medical School, Birmingham B15 2TJ
}

Evidence for the possible association of type- 2 herpes simplex virus with carcinoma of the uterine cervix arises partly from studies of in-vitro transformation of various cell types with the virus and partly from sero-epidemiological studies where patients with pre-invasive and invasive carcinoma of the uterine cervix have been shown to possess a higher average titre or greater prevalence of serum antibody to this virus than control subjects. Such studies are 
complicated by antigenic sharing between the type- 2 virus and type- 1 herpes simplex virus, there being type-common and type-specific antigens in both the intact virus particle and in the soluble virus fraction. Thus evidence of, say, type- 2 neutralising antibody activity in an individual's serum may represent previous exposure to type- 2 herpes simplex virus or may represent cross-reacting antibody from previous exposure to type-1 herpes simplex virus.

By cross-absorption techniques using heterotypic immune sera, type-specific immunoprecipitating or complement-fixing antigen preparations have been prepared. These have been used to provide specific indication of previous type-exposure in the human subject. The validity of these techniques and a preliminary indication of the prevalence and titre of antibody to type-2 herpes simplex virus in women with pre-invasive and invasive carcinoma of the uterine cervix is presented.

\title{
55. IMMUNE INHIBITION OF VIRUS RELEASE FROM CELLS INFECTED WITH HERPES SIMPLEX VIRUS
}

\author{
E. Z. Mushi and G. R. B. Skinner \\ Department of Virology, The Medical School, Birmingham B15 2TJ
}

The primary mechanism of release of herpes simplex virus from infected cells would seem to depend not entirely on cell destruction but to occur by a process of " reverse phagocytosis" with incorporation of host components into the virus envelope.

By treatment of herpes simplex virus infected cells with virus antiserum with or without complement, the titre of infectious extracellular virus was significantly reduced. This was shown to be due not to virus neutralisation but to a non-specific "immune alteration" of the infected cell membrane.

The significance of these observations with respect to the immunological control of virus infection in the human subject is discussed.

\section{DETECTION OF ANTIBODY TO HERPES SIMPLEX VIRUS BY POTASSIUM LEAKAGE}

\author{
G. K. Dhoot and G. R. B. Skinner \\ Department of Virology, The Medical School, Birmingham B15 2TJ
}

Serological detection of previous exposure to herpes simplex virus infection in the human subject has usually depended on titration of neutralising or complement-fixing serum antibody.

In recent years, a number of studies have investigated the reaction of immune and convalescent antibody on intracellular or cell surface virus antigens employing immunofluorescent or immunolytic techniques. These latter have been quantified by cell killing effects or leakage of incorporated ${ }^{51}$ Chromium from immune damaged virus-infected cells.

We have attempted to quantify immune cytolysis by measuring leakage of potassium from immune treated infected cells. The phenomenon was antibody and complement dependent and showed a similar temporal profile to the development of cell surface virus antigens; it was apparent with immune animal sera and with sera from immune human subjects. Both type-common and type-specific cell surface antigens of both type-1 and type- 2 herpes virus were involved in this phenomenon. This technique was rapid, equally reproducible and as sensitive as neutralisation kinetics and complement fixation tests. In addition, there is no requirement for expensive radioactive isotopes.

\section{SHORT PAPERS ON CLINICAL PATHOLOGY}


58. GRADE OF DIFFERENTIATION, ALPHA-FETOPROTEIN PRODUCTION AND GLUTAMATE DEHYDROGENASE ACTIVITY IN HUMAN LIVER CELL CARCINOMA

P. P. Anthony, C. L. Vogel, R. I. Glazer and K. R. McIntire Bland-Sutton Institute of Pathology and School of Pathology, Middlesex Hospital Medical School, London WIP 7LD, Emory University, Atlanta, Georgia and National Cancer Institute, Bethesda, Maryland

59. Prognostic features in testicular germ Cell tumours

J. Beilby and W. C. Parkinson

Bland-Sutton Institute of Pathology and School of Pathology, Middlesex Hospital Medical School, London WIP 7LD

60. TESTICUlar TUMOURS AND ALPHA-FETOPROTEIN

K. M. Grigor, S. I. Detre and A. Munro Neville

Institute of Cancer Research, Fulham Road, London SW3 6JB

61. OBSERVATIONS ON A $\beta$-FOETOPROTEIN ASSOCIATED WITH HUMAN NEOPLASIA

J. C. E. Underwood and S. O. Freedman

Division of Pathology, Chester Beatty Research Institute, London SW3 $6 J B$, Department of Pathology, University of Sheffield Medical School, Sheffield S10 2RX and Montreal General Hospital Research Institute, Montreal, Quebec H3G 1A4, Canada

62. STUDIES ON PREGNANCY-SPECIFIC $\beta_{1}$-GLYCOPROTEIN C. M. Towler, C. H. W. Horne and A. W. Thomson Department of Pathology, University Medical Buildings, Aberdeen AB9 2ZD

63. THYROID C CELl HYPERPLASIA IN RATS ON AN IRON DEFICIENT DIET

S. M. Triggs, R. Bailey-Wood and E. D. Williams

The Welsh National School of Medicine, Heath Park, Cardiff

64. Steroidogenic aCtivity and Responses to ACTH IN CULTURE BY AN ADRENAL CARCINOMA AND A BLACK ADENOMA CAUSING CUSHING'S SYNDROME

M. J. O'Hare, R. Magee-Brown and E. C. Nice Institute of Cancer Research, Fulham Road, London SW3 $6 J B$ 
65. An eValuation of aprotinin as an anti-tumour agent

A. W. Thomson, C. H. W. Horne and D. Tweedie Departments of Pathology and Surgery, University Medical Buildings, Foresterhill, Aberdeen AB9 $2 Z D$

66. INHIBITION OF CHICK EMBRYO CARTILAGE GROWTH BY PROSTAGLANDIN A 1

C. J. Kirkpatrick and D. L. Gardner

Institute of Pathology, Grosvenor Road, Belfast BT12 6BA

67. THE INVESTIGATION OF BREAST-TUMOUR INDUCED OSTEOLYSIS

M. Dowsett, T. J. Powles, G. C. Easty and A. Munro Neville

Institute of Cancer Research, Fulham Road, London SW3 $6 \mathrm{JB}$

68. TRANSPLACENTAL CARCINOGENESIS BY ETHYLNITROSOUREA STUDIED BY COMBINED IN-VIVO AND IN-VITRO METHODS

J. P. Roscoe and P. J. Claisse

Bland-Sutton Institute and School of Pathology, Middlesex Hospital Medical School, London WIP $7 L D$

\section{DEMONSTRATIONS}

69. A post-Mortem Study of the hip Joint. Limited And PROGRESSIVE ARTICULAR CARTILAGE ALTERATIONS

P. D. Byers, C. A. Contepomi and T. A. Farkas

Department of Morbid Anatomy, Institute of Orthopaedics, 234 Great Portland Street, London WIN 6AD

70. Pathology of midline granuloma

L. Michaels and Monica M. Gregory

Institute of Laryngology and Otology, London WC1X $8 E E$ 